Khotibatun Annisa ${ }^{1}$ Mohammd Fauziddin ${ }^{2}$

\title{
Bermain Menggambar Dekoratif untuk Meningkatkan Kemampuan Motorik Halus Anak Usia Dini
}

\begin{abstract}
Abstrak
Penelitian ini bertujuan untuk meningkatkan kemampuan motorik halus anak melalui kegiatan Kegiatan Bermain Menggambar Dekoratif pada anak kelompok B TK Mutiara Kampung Godang Bangkinang. Jenis penelitian yang digunakan adalah Penelitian Tindakan Kelas secara kolaboratif antara peneliti dengan guru kelas. Penelitian ini terdiri dari dua siklus dan setiap siklusnya dilaksanakan dua kali pertemuan. Subjek penelitian ini adalah 16 anak yang terdiri dari 5 anak laki-laki dan 11 anak perempuan. Objek penelitian adalah kemampuan motorik halus anak. Teknik pengumpulan data melalui observasi dan dokumentasi. Teknik analisis data dilakukan secara deskriptif kuantitatif. Hasil penelitian menunjukkan bahwa kemampuan motorik halus anak meningkat setelah adanya tindakan melalui kegiatan Kegiatan Bermain Menggambar Dekoratif. Langkah-langkah yang ditempuh untuk meningkatkan kemampuan motorik halus anak adalah guru mempersiapkan media dan mendemonstrasikan cara menempel/kolase. Dengan demikian, dapat disimpulkan bahwa adanya peningkatan kemampuan motorik halus naak melalui kegiatan Kegiatan Bermain Menggambar Dekoratif.
\end{abstract}

Kata kunci : Kemampuan Motorik Halus, Kegiatan Bermain Menggambar Dekoratif

\begin{abstract}
This study aims to improve fine motor skills of children through child collage in group B TK Kampung Mutiara Godang Bangkinang. This type of research is a collaborative classroom action research between researchers with classroom teachers. The study consisted of two cycles and each cycle was conducted two meetings. The subjects were 16 children consisting of 5 boys and 11 girls. The object of research is the fine motor skills of children. The technique of collecting data through observation and documentation. The data analysis technique dilkukan descriptive quantitative. The results showed that the fine motor skills of children improved after their actions through a collage. Steps were taken to improve fine motor skills of children are teachers prepare media and demonstrated how attached / collage. Thus, it can be concluded that an increase in the fine motor skills through activities decorative play
\end{abstract}

Keywords : Ability Fine Motor, Collage Event

\section{PENDAHULUAN}

Pendidikan anak usia dini (PAUD) adalah suatu upaya pembinaan yang ditujukan pada anak sejak lahir sampai berusia enam tahun yang dilakukan melalui pemberian rangsangan pendidikan untuk membantu pertumbuhan dan perkembangan jasmani dan rohani anak agar anak memiliki kesiapan dalam memasuki pendidikan lebih lanjut. (UU No 20 tahun 2003 tentang Sistem Pendidikan Nasional).

Pada usia dini otak anak berkembang sangat pesat, karena usia dini dianggap sebagai usia keemasan (golden age) yaitu masa dimana otak anak mengalami perkembangan paling cepat sepanjang sejarah kehidupannya. Periode ini hanya berlangsung pada saat anak dalam kandungan hingga usia dini, yaitu 0-6 tahun (Suyadi, 2010 : 24). Pertumbuhan dan perkembangan otak anak mencapai $80 \%$ sedangkan pada

\footnotetext{
${ }^{1}$ Prodi PGPAUD Fakultas Ilmu Pendidikan Universitas Pahlawan Tuanku Tambusai Email : khotibatun.up@gmail.com

${ }^{2}$ Prodi PGPAUD Fakultas Ilmu Pendidikan Universitas Pahlawan Tuanku Tambusai
}

Aulad : Journal on Early Childhood, 2019, 2(1), 45 - 51 
orang dewasa hanya $20 \%$ dan anak mengalami masa peka atau golden age yaitu masa dimana terjadinya pematangan fungsi-fungsi fisik dan psikis yang siap merespon stimulus yang diberikan oleh lingkungan sekitar anak.

Taman Kanak-kanak sebagai salah satu pendidikan anak usia dini memiliki peranan sangat penting untung mengembangkan kepribadian dan keterampilan anak serta mempersiapkan mereka memasuki jenjang pendidikan selanjutnya.

Taman Kanak-kanak merupakan salah satu bentuk pendidikan anak usia dini yang berada pada jalur formal yang menyelenggarakan program pendidikan bagi anak usia empat sampai enam tahun. Anak didik pada usia ini dibagi ke dalam dua kelompok belajar berdasarkan usia, yaitu kelompok A untuk anak usia 4-5 tahun, dan kelompok B untuk anak usia 5-6 tahun.

Pada anak usia 4-6 tahun, kemampuan motorik halus anak sangat diperlukan agar mereka dapat tumbuh dan berkembang secara optimal. Kemampuan motorik halus mencakup kemampuan mengamati, mengingat hasil pengamatannya dan pengalamannya. Kemampuan motorik halus anak agar dapat optimal maka diterapkan bermain sambil belajar. Bermain sambil belajar dan belajar sambil bermain mempunyai kesamaan dan perbedaan. Keduanya sama-sama melakukan kegiatan bermain sambil belajar, hanya saja penekanannya berbeda. Jika belajar sambil bermain lebih menekankan pada pembelajarannya, maka bermain sambil belajar lebih menekankan pada aktivitas bermain dan jenis permainannya.

Ada jenis permainan yang menekankan pada kemampuan tertentu. Salah satu permainan yang menekankan pada stimulasi kemampuan motorik halus anak adalah melalui kegiatan Kegiatan Bermain Menggambar Dekoratif. Dengan kegiatan Kegiatan Bermain Menggambar Dekoratif anak dapat bermain bentuk, menempel, berkarya seni, melatih kelenturan, kelincahan otot-otot jari tangan dan koordinasi antara mata dan tangan.

Perkembangan motorik ini erat kaitannya dengan perkembangan pusat motorik di otak. Keterampilan motorik berkembang sejalan dengan kematangan syaraf dan otot. Oleh sebab itu, setiap gerakan yang dilakukan anak sesederhana apapun sebenarnya merupakan hasil pola interaksi yang kompleks dari berbagai bagian dan sistem tubuh yang dikontrol anak. Perkembangan motorik sangat berperan dengan perkembangan lainnya seperti perkembangan fisiologis anak, perkembangan sosial emosional anak, dan perkembangan kognitif anak. Oleh sebab itu, dengan meningkatnya motorik anak maka akan meningkatkan perkembangan lainnya. (Sujiono. B, dkk 2010 : 1.5-1.7).

Perkembangan motorik anak terbagi menjadi dua bagian, yaitu motorik kasar dan motorik halus. Motorik halus bagi anak usia dini merupakan suatu hal yang sangat penting bagi perkembangan anak. Anak membutuhkan belajar menggunakan tangan dengan baik untuk keterampilan hidup, seperti makan dan memakai pakaian sendiri. Mereka belajar mengkoordinasikan mata dan gerakan tangan. Selain itu motorik halus anak berpengaruh pada kesiapan anak dalam menulis yaitu untuk masuk ke jenjang yang lebih tinggi lagi.

Menurut Sujiono. B, dkk (2010: 12.5) motorik halus adalah gerakan-gerakan tubuh yang melibatkan otot-otot kecil misalnya otot-otot jari tangan, otot muka, dan lain-lain. Gerakan motorik halus, terutama yang melibatkan otot tangan dan jari biasanya membutuhkan kecermatan tinggi, ketekunan dan koordinasi antara mata dan otot kecil. Beberapa gerakan yang dapat dimasukkan kedalam gerakan motorik halus, misalnya menggunting, merobek, menggambar, menulis, melipat, meronce, menjahit, meremas, menempel, menggenggam, menyusun balok, meringis, melotot, tertawa dan sebagainya. 
Berdasarkan hasil observasi dan wawancara di TK Mutiara Kampung Godang pada tanggal 4 Februari 2016, dalam proses mengembangkan motorik halus anak masih rendah. Hanya beberapa anak pada kelompok B yang bisa menempel dengan baik. Khususnya pada kegiatan kegiatan Kegiatan Bermain Menggambar Dekoratif anak mengalami kesulitan dan media yang digunakan kurang menarik, sehingga apa yang diharapkan tidaklah sesuai dengan tujuan pembelajaran yang ingin dicapai yaitu pada aspek perkembangan motorik halus anak.

Tujuan penelitian ini adalah untuk mengetahui peningkatan motorik halus anak melalui kegiatan kolase pada anak kelompok B TK Mutiara Kampung Godang Bangkinang.

Sujiono. B,dkk (2010 : 1.17) menjelaskan bahwa motorik adalah gerakan yang hanya melibatkan bagian-bagian tubuh tertentu saja dan dilakukan oleh otot-otot kecil seperti keterampilan menggunakan jari-jemari tangan dan gerakan pergelangan tangan.

Menurut Gunarti. W, dkk (2010 : 1.32) motorik halus adalah gerakan yang membutuhkan otot-otot kecil dan tidak memerlukan tenaga besar, seperti menulis, menggunting, melipat, meronce, dan sejenisnya.

Menuruk Hurlock (dalam Suyadi 2010 : 69) perkembangan motorik halus anak adalah meningkatnya pengoordinasian gerak tubuh yang melibatkan otot dan syaraf yang jauh lebih kecil detail. Kelompok otot dan syaraf inilah yang nantinya mampu mengembangkan gerak motorik halus, seperti meremas kertas, merobek, menggambar, menulis, dan lain sebagainya.

Keterampilan motorik halus merupakan komponen yang mendukung pengembangan yang lainnya seperti pengembangan kognitif, sosial dan emosional anak. Pengembangan kemampuan motorik yang benar dan bertahap akan meningkatkan kemampuan kognitif anak sehingga dapat terbentuk kemampuan kognitif yang optimal. Pengembangan keterampilan motorik halus dapat ditunjukkan dalam kemampuan kognitif anak yaitu ditunjukkan dengan kemampuan mengenali, membandingkan, menghubungkan, menyelesaikan masalah sederhana dan mempunyai banyak gagasan tentang berbagai konsep dan gejala sederhana yang ada di lingkungannya. Kurangnya kesempatan berpartisipasi dalam salah satu kegiatan motorik akan memperlambat pertumbuhan dan intelektual anak (Sumantri, 2005: 144-145).

Berdasarkan kutipan diatas, maka pengertian motorik halus adalah pengorganisasian penggunaan otot-otot kecil seperti jari-jemari dan tangan yang sering membutuhkan kecermatan koordinasi mata dan tangan. Gerakan motorik halus anak apabila gerakan hanya melibatkan bagian-bagian tubuh tertentu saja dan dilakukan oleh otot-otot kecil, seperti keterampilan menggunakan jari-jemari tangan dan pergelangan tangan yang tepat. Gerakan motorik halus yang terlihat saat usia TK, antara lain adalah anak mulai menyikat giginya, menyisir, membuka dan menutup retsluiting, memakai sepatu sendiri, mengancingkan pakaian, serta makan sendiri dengan menggunakan sendok dan garpu (Sujiono. B, dkk 2010 : 1.14).

Gerakan motorik halus pada anak juga memerlukan dukungan keterampilan fisik lain serta kematangan mental, anak juga memerlukan kemampuan kognitif yang memungkinkan terbentuknya sebuah gambar (Sujiono.B, dkk 2010 : 1.14). Semakin baiknya gerakan motorik halus anak membuat anak dapat berkreasi, seperti menggunting kertas dengan hasil guntingan yang lurus, menggambar gambar sederhana dan mewarnai, menggunakan klip untuk menyatukan dua lembar kertas, menjahit, menganyam kertas serta menajamkan pensil dengan rautan pensil. Namun tidak semua anak memiliki kematangan untuk menguasai kemampuan ini pada tahap yang sama.

Standar kompetensi kurikulum TK tercantum bahwa tujuan pendidikan di Taman kanak-kanak adalah membantu mengembangkan berbagai potensi anak baik psikis dan 
fisik yang meliputi moral dan nilai-nilai agama, sosial emosional, kognitif, bahasa, fisik motorik, kemandirian dan seni untuk memasuki pendidikan dasar (Sujiono. B, dkk 2010 :2.10).

Tujuan pengembangan motorik halus anak 4-6 tahun adalah: (1) mampu mengembangkan kemampuan motorik halus yang berhubungan dengan keterampilan gerak kedua tangan, (2) mampu menggerakkan anggota tubuh yang berhubungan dengan gerak jari-jemari: seperti persiapan menulis, menggambar dan memanipulasi benda-benda, (3) mampu mengkoordinasi indra mata dan tangan, dan (4) mampu mengendalikan emosi dalam beraktivitas motorik halus.

Secara khusus tujuan pengembangan motorik halus adalah anak dapat menunjukkan kemampuan menggerakan anggota tubuhnya dan terutama terjadinya koordinasi mata dan tangan sebagai persiapan untuk pengenalan menulis (Puskur,Balitbang Depdiknas,2002).

Adapun cara mengembangkan kemampuan motorik halus di TK adalah sebagai berikut (Wardani 2011:48) : (1) memberi kesempatan belajar anak untuk mempelajari kemampuan motoriknya, agar ia tidak mengalami keterlambatan perkembangan, (2) memberi kesempatan mencoba seluas luasnya, agar ia bisa menguasai kemampuan motoriknya, (3) memberikan contoh yang baik karena mempelajari dan mengembangkan kemampuan motoriknya lewat cara meniru, (3) memberikan bimbingan karena meniru tanpa bimbingan tak akan mendapatkan hasil optimal.

Menurut Sumantri (2005:147-148) pengembangan motorik halus anak usia dini hendaknya memperhatikan beberapa prinsip-prinsip sebagai berikut: (1) merorentasi pada kebutuhan anak. Anak usia dini adalah masa yang sedang membutuhkan stimulasi secara tepat untuk mencapai optimalisasi seluruh aspek pengembangan baik secara fisik maupun psikis. Dengan demikian, ragam jenis kegiatan pembelajaran hendaknya dilakukan melalui analisa kebutuhan yang disesuaikan dengan berbagai aspek perkembangan dan kemampuan pada masing-masing anak. (2) belajar sambil bermain. Upaya stimulasi anak usia dini hendanya dilakukan pada situasi yang menyenangkan. Menggunakan pendekatan bermain anak diajak untuk bereksplorasi, menemukan dan memanfaatkan objek-objek yang dekat dengannya sehingga diharapkan kegiatan akan lebih bermakna. (3) kreatif dan inovatif. Aktivitas kreatif dan inovatif dapat dilakukan oleh pendidik melalui kegiatan-kegiatan yang menarik, membangkitkan rasa ingin tahu anak, memotivasi anak untuk berpikir kritis, dan menemukan hal-hal baru.

Kolase secara bahasa ialah berasal dari bahasa Prancis "collage " yang berarti lem/tempel. Sedangkan secara istilah kolase adalah kreasi aplikasi yang dibuat dengan mengabungkan teknik melukis (lukisan tangan) dengan menempelkan bahan-bahan tertentu. Jadi bisa dikatakan kolase adalah sebuah teknik menempel unsur-unsur berbeda (bisa berupa kain, kertas, kayu, dan lain-lain) kedalam sebuah frame sehingga menghasilkan sebuah karya seni yang baru.

Menurut kamus besar Bahasa Indonesia adalah komposisi artistik yang dibuat dari berbagai bahan (kain, kertas, kayu) yang ditempelkan pada permukaan gambar (Depdiknas. 2001 : 580). Kegiatan Bermain Menggambar Dekoratif merupakan kegiatan menggambar hiasan/ ornament pada kertas gambar ata pada benda-benda tertentu (prawira:2004.)

\section{METODE PENELITIAN}

Jenis penelitian ini adalah Penelitian Tindakan Kelas. Menurut Wardhani dan Kuswaya W (2011 : 1.15) Penelitian Tindakan Kelas (PTK) adalah penelitian yang dilakukan oleh guru di kelasnya sendiri melalui refleksi diri dengan tujuan untuk memperbaiki kinerjanya sehingga hasil belajar anak meningkat. Sesuai dengan tujuan

Aulad : Journal on Early Childhood, 2019, 2(1), 45 - 51 
penelitian dilakukan untuk meningkatkan kemampuan motorik halus anak melalui kegiatan kolase pada anak kelompok B TK Mutiara Kampung Godang.

Instrumen penelitian adalah alat atau fasilitas yang digunakan oleh peneliti dalam mengumpulkan data agar pekerjaannya lebih mudah danhasilnya lebih baik, dalam arti cermat, lengkap dan sistematis sehingga lebih mudah diolah (Arikunto, S. 2006: 160). Instrumen penelitian merupakan alat yang digunakan peneliti untuk mengumpulkan data sesuai dengan variabel yang telah ditetapkan dalam penelitian.

Analisis data merupakan upaya mencari dan menata data secara sistematis untuk meningkatkan pemahaman peneliti tentang kasus yang diteliti dan menyajikannya sebagai temuan bagi orang lain Sumarni, S (2012 : 98). Data yang dikumpulkan akan diolah dengan cara memberi makna pada data tersebut dan dipergunakan persentase.

Tujuan analisis dalam penelitian tindakan kelas ini adalah untuk memperoleh kepastian apakah terjadi perbaikan, peningkatan, atau perubahan sebagaimana yang diharapkan bukan untuk membuat generalisasi atau pengujian teori. Setelah melakukan pengumpulan data dengan lengkap, selanjutnya penulis berusaha menyusun dan mengelompokkan data serta menyeleksi data yang ada dalam penelitian ini. Hal ini berfungsi sebagai jawaban atas rumusan masalah yang telah ditetapkan. Setelah dikelompokkan selanjutnya data dipersentase agar data tersebut mempunyai arti dan dapat ditarik pada suatu kesimpulan umum.

Metode analisis yang digunakan dalam penelitian ini adalah deskriptif kuantitatif. Deskriptif kuantitatif digunakan untuk menganalisis data berupa angka.Teknik analisis data ini diperoleh dengan cara merefleksi hasil observasi terhadap pembelajaran yang dilaksanakan oleh guru dan peserta didik di kelas. Data yang diperoleh dalam penelitian ini berupa hasil observasi.

Data observasi yang telah diperoleh kemudian dilakukan analisis secara deskriptif, sehingga mampu memberikan gambaran yang jelas tentang pembelajaran yang dilakukan guru dan anak pada saat pembelajaran kegiatan kolase berlangsung.

Penelitian kelas ini dilaksanakan di TK Mutiara Kampung Godang Kecamatan Bangkinang Kabupaten Kampar yang beralamat di Jl. Peltu Syaidan No. 19 Kampung Godang. TK Mutiara Kampung Godang saat ini berada di bawah kepemimpinan ibu Ratnawilis. Subjek penelitian ini adalah anak Kelompok B TK Mutiara Kampung Godang Bangkinang. Kelompok B TK Mutiara Kampung Godang 16 anak yang terdiri dari 5 anak laki-laki dan 11 anak perempuan yang rentang usianya 5-6 tahun, namun ada 1 anak yang usianya dibawah 5 tahun.

Kondisi ruang kelas TK Mutiara Kampung Godang cukup baik, terdapat beberapa hiasan didinding kelas, sudah terdapat rak buku untuk menyimpan buku-buku dan alatalat tulis sebagai penunjang pembelajaran dan rak tas untuk meletakkan tas anak. Kondisi diluar kelas terdapat rak sepatu untuk meletakkan sepatu anak-anak. Fasilitas alat permainan sudah cukup lengkap. Sarana dan prasarana yang tersedia di TK Mutiara Kampung Godang yaitu memiliki 4 ruangan yang terdiri dari 1 ruang untuk kantor, 1 ruang untuk belajar, 1 ruang untuk kamar mandi dan 1 ruang untuk gudang dan tempat parkir. Adapun alat permainan luar meliputi: luncuran, jungkat-jungkit, ayunan dan jaring laba-laba.

\section{HASIL DAN PEMBAHASAN}

Pembelajaran di Taman Kanak-kanak harus dilakukan dengan menyenangkan. Banyak hal yang dapat dilakukan agar pembelajaran menyenangkan misalnya dengan menggunakan berbagai media pembelajaran dan guru yang aktif. Menurut Zaman. B, dkk (2009 : 4.12) media pembelajaran berfungsi untuk meningkatkan kualitas proses pembelajaran. Sehingga dengan penggunaan media yang menarik dan guru yang aktif

Aulad : Journal on Early Childhood, 2019, 2(1), 45 - 51 
suasana dikelas menjadi menyenangkan, hidup serta dapat meningkatkan kualitas pembelajaran. Guru juga berperan sangat penting dalam membantu mengembangkan motorik halus anak dengan memotivasi anak. Motivasi yang datang dari dalam diri anak perlu didukung dengan motivasi yang datang dari luar.

Perkembangan motorik halus anak kurang berkembang optimal jika tidak ada motivasi serta dorongan dari guru. Pada saat pelaksanaan kegiatan kolase dengan bahan yang bervariasi di TK Mutiara Kampung Godang guru memotivasi semua anak, khususnya pada anak yang belum mampu menempel dengan baik. Setelah dilakukan tindakan, pada siklus I anak sudah mulai mampu menempel dengan baik mesti perlu bantuan atau bimbingan dari guru. Pada siklus II anak-anak sudah menunjukkan peningkatan kemampuan motorik halus anak, dengan melihat hasil karya anak yang sudah rapi, bersih, dan ketelitian anak dalam kegiatan kolase. Anak-anak terlihat antusias dalam kegiatan tersebut.

Kemampuan motorik halus anak dapat dilihat dari perbandingan pra tindakan, siklus 1 dan siklus 2 .

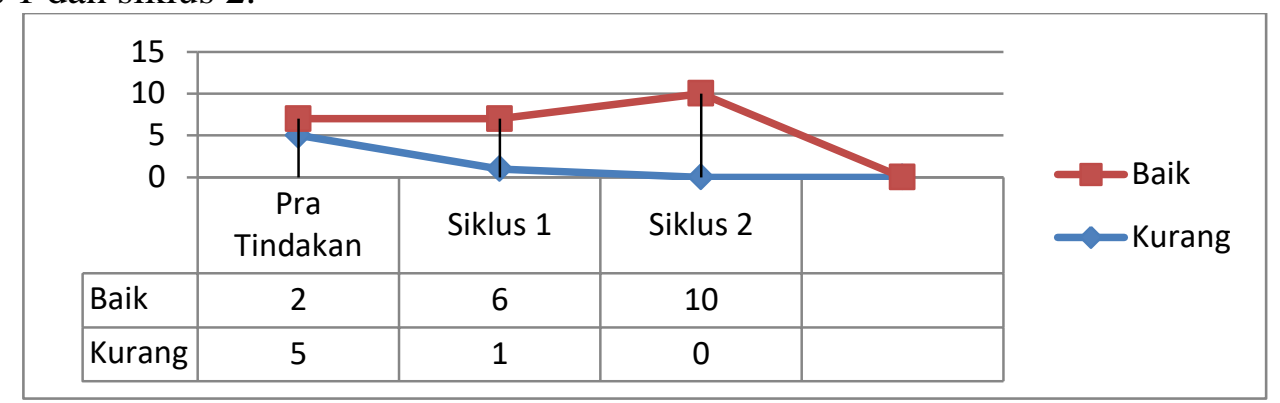

Dari hasil penelitian yang telah diuraikan diatas serta dengan observasi langsung dengan menggunakan lembar observasi dan dokumentasi, dapat diketahui adanya peningkatan perkembangan motorik halus anak melalui kegiatan kolase pada anak kelompok B TK Mutiara Kampung Godang. Peningkatan ini dapat dilihat dengan hasil yang diperoleh pada Pratindakan, Siklus I, dan Siklus II.

\section{KESIMPULAN}

Melalui kegiatan kolase dapat meningkatkan kemampuan motorik halus anak usia dini. Peningkatan tersebut dapat dilihat dari adanya peningkatan persentase dari tahap Pra Tindakan dan setelah dilakukan tindakan kelas. Kegiatan Kolase yang dilaksanakan oleh guru menggunakan bahan yang aman dan mudah didapat serta murah. Kolase menarik perhatian anak sehingga mereka dapat belajar dengan senang.

\section{DAFTAR PUSTAKA}

Arikunto Suharsimi, dkk. (2010). Penelitian Tindakan Kelas. Jakarta: PT Bumi Aksara. Guniarti, W, dkk. (2010). Metode Pengembangan Perilaku dan Kemampuan dasar Anak Usia Dini. Jakarta: Universitas Terbuka

Kristiani, A (2015). Meningkatkan Kemampuan Motorik Halus Anak melalui Bermain Kolase Pada Anak Kelompok A TK Dharma Wanita Kecamatan Ngasem Kabupaten Kediri Tahun Ajaran 2014/2015. Universitas Nusantara PGRI Kediri : Skripsi Tidak Dipublikasikan

Mardiati, E (2013). Peningkatan Kemampuan Motorik Halus Anak melaui Kegiatan Kolase dengan menggunakan Media Berbahan Alam di PAUD Melati Kabupaten Lebong. Universitas Bengkulu : Skripsi Tidak Dipublikasikan

Margono, S. (2010). Metodologi Penelitian Pendidikan. Jakarta: PT Rineka Cipta. 
Mayasari, R (2014). Meningkatkan Motorik Halus Anak melalui Kegiatan Melipat Kertas Pada Anak Kelompok B4 di Tk Masjid Syuhada. Universitas Negeri Yogyakarta, Yogyakarta: Skripsi Tidak Dipublikasikan.

Menteri Pendidikan Nasional. (2014). Peraturan Menteri Pendidikan Nasional Nomor 137 tentang Standar Pendidikan Anak Usia Dini. Jakarta:Departemen Pendidikan Nasional.

Moeslichatoen, R. (2004). Metode Pengajaran di Taman Kanak-kanak. Jakarta: PT Rineka Cipta.

Moeslichaton (2004). Metode Pengajaran di Taman Kanak-Kanak, Jakarta, Rineka Cipta, 2004

Pamadhi. H \& Evan S. S (2011), Seni Keterampilan Anak. Jakarta : Universitas Terbuka

Samsudin (2008), Pembelajaran Motorik di Taman Kanak-Kanak, Litera Prenada Media Group, Jakarta 2008

Sujiono, B, dkk (2010), Metode Pengembangan Fisik. Jakarta : Universitas Terbuka

Sumarni, S. (2012). Metodologi Penelitian Pendidikan. Yogyakarta: Insan Madani.

Suyadi. (2010). Psikologi Belajar Pendidikan Anak Usia Dini. Yogyakarta: Pedagogia.

Syakir Muharrar (2008), Sri Verayanti, Kolase Montase, Mozaik, Erlangga, Jakarta, 2013

Wardhani dan Kuswaya W (2011). Penelitian Tindakan Kelas. Jakarta : Universitas Terbuka 